\title{
Populist online communication: Interactions among politicians, journalists, and citizens (Dissertation summary)
}

Sina Blassnig, University of Zurich, Department of Communication and Media Research IKMZ, Switzerland

s.blassnig@ikmz.uzh.ch

Swiss Association of Communication and Media Research (SACM) - Dissertation Award 2021

Sina Blassnig has been awarded the SACM Dissertation Prize 2021, which honors the best PhD thesis in communication and media sciences completed at a Swiss university or by a Swiss researcher. SComS is happy to publish a summary of Sina Blassnig's (University of Zurich) winning $\mathrm{PhD}$ thesis entitled "Populist online communication: Interactions among politicians, journalists, and citizens".

\begin{abstract}
The recent rise of populist politicians in Western democracies is often associated with their allegedly successful use of digital media. However, for a long time, there has been little research specifically on populist online communication. To address this substantial research gap, the thesis pursues two major research aims: First, it investigates drivers of populist communication in politicians' online self-presentation and online news media representation. Second, the thesis examines the effects of populist online communication on citizens' behavior in the form of user reactions to politicians' social media posts and reader comments on online news articles. Based on five internationally comparative studies and the overarching synopsis, the cumulative thesis demonstrates that populist online communication is driven by the reciprocal interactions among politicians, journalists, and citizens and is influenced by various factors on the macro, meso, and micro level. Furthermore, it shows that populist online communication resonates with citizens and is multiplied by them - specifically by citizens with prior strong populist attitudes. By analyzing the interactions of three key actor groups - politicians, journalists, and citizens - and by following a multimethod approach the dissertation connects research on both the supply and demand side of populism.
\end{abstract}

\section{Keywords}

populism, online communication, online news, social media, user reactions

\section{Introduction}

"The others have newspapers, radio, television, banks, and corporate money - we have you, we have the network," ${ }^{1}$ Matteo Salvini (2018) told his followers in a video posted on Facebook in February 2018, one month before the leader of the populist right-wing party Lega Nord became Minister of the Interior and Deputy Prime Minister of Italy. Salvini's message is reminiscent of statements by other politicians. In recent years, the open disdain that mostly

1 Translation by the author. right-wing - as well as some left-wing politicians have shown for the mainstream news media has been a recurrent theme in political campaigns in Western democracies. Relatedly, the attempts of these politicians to bypass the mainstream news media through social media are frequently discussed. In particular, the rise of populist politicians and parties is often associated with their allegedly successful use of social networking sites - and often seen as signs of a "populist Zeitgeist" that Mudde (2004) had predicted more than a decade earlier. 
At the end of the last century, Blumler and Kavanagh (1999, pp. 219-220) argued that the expansion of media outlets and the associated new opportunities for the public to become politically active would increase populist tendencies and anti-elitist popularization. Around the same time, Bimber (1998) claimed that the Internet might promote an "unmediated" communication between citizens and the government that would increase citizen influence on politics at the expense of elites and political intermediaries, such as traditional political parties and the mainstream press. Today, the assumption that politicians use the Internet to bypass traditional mass media and communicate directly with their followers is mostly applied to their self-presentation on social media (e.g., Parmelee \& Bichard, 2012). As the quote above shows, populists often make this claim themselves. At the same time, populist actors regularly succeed in attracting the attention of the mass media with their provocative statements that cater to media logic and news values (Mazzoleni, 2008). Thus, in a hybrid media system (Chadwick, 2017), populist actors may also use social media to gain attention in the mass media. The digitization of traditional news media leads to an increased commercialization and audience orientation that could make online news media even more susceptible to populist statements (Aalberg \& de Vreese, 2017). Furthermore, online media provide citizens with more possibilities for direct feedback and interaction, for example via likes, shares, or comments.

Scholarly awareness of the crucial role of populist communication and empirical research in this area have increased immensely in the last few years. However, despite the early linking of populism and the Internet by Bimber (1998), for a long time there was hardly any scientific knowledge about the occurrence and effects of populist online communication. Thus, many questions remain unanswered. First, there is still scarce research on what constitutes the supposed affinity between digital media and populism, to what extent actors use populist communication online, and what contextual factors or op- portunity structures promote the use of populist online communication. Second, whereas research on populism and social media has increased, these platforms are still often looked at in isolation and rarely compared to other digital or traditional communication channels as part of a larger information system (de Vreese, Esser, Aalberg, Reinemann, \& Stanyer, 2018). Specifically, the role of online news media has been neglected, despite the fact that the mass media continue to play a central part in the rise of recent populist actors (e.g., Esser, Stępińska, \& Hopmann, 2017). Third, although vast literature argues that citizens have come to play a more active part in digital journalism, their role in populist communication remains underresearched. Very few studies investigate the effects of populist communication on citizens' behavior or specifically in an online context. Moreover, there are only few field studies that examine the effects of populist communication outside of an experimental context. Finally, the supply side and the demand side of populism are still mostly looked at separately. To address these substantial research gaps, the dissertation sets out to answer two overarching questions:

1. What are the drivers of populist online communication with regard to (a) politicians' online self-presentation and (b) its representation in the online news media?

2. What effects does populist online communication have on citizens' reactions in response to (a) politicians' self-presentation and (b) its representation in the online news media?

These questions build the foundation of the cumulative dissertation and are empirically assessed in five related publications. The dissertation extends previous research by looking at populist communication across different online media platforms and by investigating the interaction of three key actor groups - (1) politicians, (2) journalists, and (3) citizens - that have so far often been investigated separately. I analyze (1) how politicians use populist 
communication in their self-presentation, (2) how journalists represent populist ideas in the mass media, and (3) how citizens respond to populist communication in the form of user reactions to politicians' social media posts and reader comments in response to online news articles. With regard to politicians' self-presentation, I contribute to the literature by examining populism in the communication of a broad range of political actors across the political spectrum and different communication channels. In relation to the role of journalists, as de Vreese et al. (2018, p. 432) urge, I consider the media both as a platform for transmitting populist messages by politicians through the media and as possible initiators of populist messages in the form of populism by the media (Esser et al., 2017). With regard to citizens, I explore the role of populist citizen journalism (Esser et al., 2017) in the form of populist reader comments as well as the effects of populist online communication on citizens' manifest behavior in the form of popularity cues (Porten-Cheé, Haßler, Jost, Eilders, \& Maurer, 2018). Finally, by investigating both drivers and effects of populist online communication and by combining content analysis, digital trace data, and an experimental survey, I connect research on the supply side and the demand side of populism.

\section{Theoretical framework}

The thesis follows an ideational approach (Hawkins \& Kaltwasser, 2018) and understands populism as a "thin" ideology that describes a Manichean conflict between "the people" and "the elite" over sovereignty in society (Mudde, 2004). Furthermore, the homogenous conceptualization of "the people" as the favored in-group implies that there are specific social groups that are excluded from the people as "others" (Albertazzi \& McDonnell, 2008). Depending on the parsimony of the conceptualization, populism as a "thin" ideology therefore consists of three (Mény \& Surel, 2002; Wirth et al., 2016) or four (Albertazzi \& McDonnell, 2008; Engesser,
Fawzi, \& Larsson, 2017) dimensions: people-centrism, anti-elitism, popular sovereignty, and the exclusion of "others".

On the supply side, populism can be investigated in the form of populist communication that manifests in political discourse. Populist ideology can be communicated by various actors by means of specific populist key messages. From a political communication perspective, three key actor groups are of particular interest as populist communicators: political actors, the media, and citizens (de Vreese et al., 2018). On the demand side, populism manifests in the form of populist attitudes of citizens at the individual or aggregated mass level (Akkerman, Mudde, \& Zaslove, 2014). These populist attitudes can be conceived of as a latent demand or a disposition that can be activated by populist communication (Hawkins \& Kaltwasser, 2018; Krämer, 2014). Furthermore, populist communication is expected to have effects on different attitudes and behaviors of citizens that may be explained theoretically by priming, framing, blame attributions, social identity theory, or emotional persuasion processes (Hameleers, Bos, \& de Vreese, 2017; Hawkins \& Kaltwasser, 2018; Krämer, 2014; Wirz, 2018).

Recent literature suggests that online and social media provide specific opportunity structures for populist communication and populist actors (Aalberg \& de Vreese, 2017; Engesser et al., 2017). However, within a hybrid media system, older and newer media logics compete and complement each other (Chadwick, 2017, p. 207). This hybridity becomes visible in the interplay not only between online and offline channels but also within political online communication. In addition to noninstitutionalized online communication platforms such as social media, traditional, well-known media brands have established themselves online (see, e.g., Humprecht, 2016). Journalistic and social media outlets follow different media logics, which may influence their roles as platforms for populist communication. Furthermore, online media allow for a more direct interaction between politicians, journalists, and citizens within the 
same platforms and therefore potentially change the relationship between these three actor groups. Therefore, populist online communication is conceptualized as the interplay between (1) populist communication in politicians' online self-presentation, (2) journalists' online media representation of populist communication, and (3) citizens' responses to this written and posted content in the form of audience reactions.

Following a communication-centered approach (Stanyer, Salgado, \& Strömbäck, 2017), it is assumed that politicians' communication can be populist to varying degrees. This leads to the question of what factors might explain the use of populist key messages. First, characteristics of the communication channel may act as drivers of populism in politicians' self-presentation. Specifically, news media logic, network media logic, or generally a highly audience-oriented logic offer several opportunity structures for populist communication (Ernst, Engesser, Büchel, Blassnig, \& Esser, 2017; Landerer, 2013; Mazzoleni, 2008). In addition, specific characteristics of political parties such as an extreme ideological position have been identified as potential drivers of populist communication in politicians' self-presentation (Ernst et al., 2017; Ernst, Esser, Blassnig, \& Engesser, 2019).

Despite the growing importance of social media, the news media are crucial for the wider dissemination of populist communication. Journalists can take on different roles as initiators, gatekeepers, or interpreters of populist messages (Wettstein, Esser, Schulz, Wirz, \&Wirth, 2018). First, as initiators journalists can express populist ideas themselves in the form of populism by the media (Esser et al., 2017). Second, described as populism through the media, journalists as gatekeepers can disseminate and thereby reinforce populist messages by other actors, mostly by politicians (Esser et al., 2017). Third, as interpreters of populist messages, journalists can attenuate or amplify, criticize, or legitimize populist messages by politicians (Wettstein et al., 2018). In online news outlets, journalists may be specifically likely to voice or cite populist statements due to an increasing audience orientation, the attention economy, commercialization, and an orientation toward news values and network media logic. Additionally, specific characteristics of news coverage, such as opinion-oriented formats or interpretative journalism, may act as drivers of populist online communication. Finally, these tendencies may be reinforced by soliciting the active feedback, distribution, and participation of readers.

The increasing audience-orientation and possibilities for citizens' direct feedback in an online environment make citizens the third central actor group for populist online communication. The dissertation examines both the effects of populist communication on citizens as $r e$ cipients and on their subsequent behavior as actors in populist communicative interactions (de Vreese et al., 2018). Thereby, I specifically focus on three aspects: (1) user reactions to populist communication in the form of popularity cues (Porten-Cheé et al., 2018); (2) reader comments as populist citizen journalism (Esser et al., 2017); and (3) how the former two aspects can be conceptualized as effects of populist communication. In this regard, the thesis integrates theoretical perspectives on network media logic (Klinger \& Svensson, 2015), the role of reader comments in the online public sphere (Dahlberg, 2001; Freelon, 2015; Toepfl \& Piwoni, 2015), and different persuasion processes such as schema theory (Krämer, 2014), priming (RoskosEwoldsen, Roskos-Ewoldsen, \& Carpentier, 2002), and social identity theory (van Zomeren, Postmes, \& Spears, 2008).

\section{Method and data}

The cumulative dissertation comprises five publications that draw on four data collections to investigate populist communication across different countries and communication contexts. I analyze social media posts of politicians, online news media content, and their effects on citizens' reactions in the form of popularity cues and reader comments in up to six 
countries. Thereby, I draw on quantitative content analysis, digital trace data, and an online survey experiment to combine the supply and demand sides and to complement the advantages and disadvantages of the different approaches.

\subsection{Comparative approach}

The dissertation follows a comparative approach, analyzing the manifestation of populist communication and its effects across different countries, communication channels, and actor types. All content analyses (Articles $I-I V$ ) include several countries in their research design. However, they differ somewhat in their approach. Article I follows the most explicit comparative approach by comparing the use of populist communication across four countries - Switzerland $(\mathrm{CH})$, Germany (DE), the United Kingdom (UK), and the United States (US) - and by investigating structural aspects on the macro level as explanatory factors. This allows investigating politicians' use of populist communication in varying political and electoral settings and explaining differences and similarities through different contextual settings (Esser \& Hanitzsch, 2012). In Articles II, III, and IV, the comparative approach serves more as a comparison of relations, in which the different contexts work as a robustness check and enable a higher generalizability of the findings within Western Europe (Esser \& Vliegenthart, 2017). Articles II and IV follow a most different systems within most similar systems design in the selection of the countries (Switzerland, France, and United Kingdom). For Article III, six Western democracies were selected: Switzerland $(\mathrm{CH})$, Germany (DE), France (FR), Italy (IT), the United Kingdom (UK), and the United States (US), providing even more diverse contexts.

\subsection{Research design, methods, and data}

Article I is based on a quantitative content analysis of politicians' statements in political talk shows and on social media (Facebook and Twitter) in four countries (CH, DE, UK, US). The material was manually coded by the author of the disser- tation. This study focuses on politicians' self-presentation and includes statements by 74 politicians across the political spectrum during a routine time in 2014 $(N=2454)$ (for more details see Blassnig, Ernst, Büchel, \& Engesser, 2018).

Articles II and $I V$ draw on a quantitative content analysis of online news coverage related to the topic of immigration and responding reader comments during national election campaigns in France (2017), Switzerland (2015), and the United Kingdom (2015). These data were manually coded by a team of intensively trained student coders. The data set includes $N=493$ news articles from 14 online media outlets and $N=2904$ reader comments (for more details see Blassnig, Engesser, Ernst, \& Esser, 2019; Blassnig, Ernst, Büchel, Engesser, \& Esser, 2019).

Article III is based on a quantitative content analysis of Facebook posts and tweets from 36 political leaders of 29 parties $(N=566)$ across six countries $(\mathrm{CH}$, DE, FR, IT, UK, US) during a routine time in 2015. Again, these data were manually coded by a team of intensively trained student coders (for more details see Blassnig, Ernst, Engesser, \& Esser, 2020).

Article $V$ draws on data from an online survey experiment with a $2 \times 2$ design. The experiment was conducted in Switzerland in 2019. The participants were recruited by a market research company from its online access panel using quota sampling for age, gender, and education based on Eurostat data for German-speaking Facebook users in Switzerland $(N=647)$ (for more details see Blassnig \& Wirz, 2019).

\subsection{Operationalization of populist communication}

The most crucial variable of the dissertation is populist communication. It serves as the dependent variable in Articles I, II, and $I V$, as an independent variable in $A r$ ticles $I I I$ and $I V$, and as the experimental factor in Article $V$. Its operationalization was derived directly from the theoretical definition of populist ideology, building on previous literature (Cranmer, 2011; Ernst et al., 2017; Jagers \& Walgrave, 2007; Wirth et al., 2016). Overall, populist communi- 
cation is regarded as a formative measure, based on twelve populist key messages related to the four dimensions people-centrism, anti-elitism, restoring sovereignty, and the exclusion of others.

\section{Key findings}

Article I (Blassnig et al., 2018) focuses on politicians' self-presentation. It investigates how politicians across the political spectrum employ populist communication in talk shows and on social media in four countries and shows that populist communication is context-dependent. It finds a most complete populism in Switzerland, a more anti-elitist populism in Germany and the United Kingdom, and a mostly empty populism in the United States. Moreover, the politicians' communication is more populist in talk shows than on social media, and extreme parties are more anti-elitist and excluding but not more people-centrist than moderate or center parties are.

Article II (Blassnig, Ernst, et al., 2019) shifts the focus from social media to online news coverage and attendant reader comments. The paper provides empirical evidence for the distinction between populism by the media and populism through the media (Esser et al., 2017). It finds that, first, the majority of populist key messages in online news articles originate from politicians, not from journalists. Second, populist communication by journalists is higher in opinion-oriented stories, whereas populism by political actors is higher in straight news articles. Third, journalists rarely explicitly attenuate or criticize populist statements by political actors. Finally, the article finds that the reader comment sections are more populist than the online news articles.

Article III (Blassnig et al., 2020) investigates the effects of populist communication in political leaders' self-presentation on social media on the number of popularity cues they receive. It finds that populist posts receive more popularity cues than non-populist posts - but only on Facebook not on Twitter. Posts of po- litical leaders that communicate more populist on average, have a higher popularity or reach on both platforms. Leaders of pre-defined typical populist parties receive a higher social media response than leaders of typically non-populist parties overall - but they do not profit more from communicating populist key messages.

Article IV (Blassnig, Engesser, et al., 2019) focuses more closely on citizens and an effects perspective by analyzing how populist statements by journalists and politicians in online news articles affect the number and content of reader comments by citizens. The article demonstrates that populist communication by politicians and journalists in online news triggers (a) more frequent reader comments and (b) more populist reader comments, (c) regardless of whether the journalists moderate populist messages by political actors or not.

Article V (Blassnig \& Wirz, 2019) is based on an experimental survey with a $2 \times 2$ design comparing populist vs. nonpopulist messages in Facebook posts by typically populist vs. non-populist politicians as the source of the message. The results show that both, populist messages and populist actors, foster the recipients' perception of a Facebook post as populist, but only populist messages are drivers of user reactions. The study further demonstrates that the effect of populist communication on user reactions is moderated by recipients' prior populist attitudes: Only users with strong populist attitudes are more likely to share populist messages than non-populist messages. Finally, this study finds an unexpected negative interaction between populist communication and populist actor; recipients were more likely to react - specifically to comment on populist messages if they came from the non-populist actor.

The key findings of the dissertation can be connected and summarized in four main conclusions with regard to populist online communication: First, politicians' self-presentation on social media is not inherently more populist compared to other communication channels. Although social media provide several opportunity 
structures for populist communication, politicians' use thereof is influenced by additional factors such as the situational context, the issue, or party characteristics. However, populist social media messages may receive disproportional attention, both directly from followers - specifically on Facebook - and indirectly via traditional mass media. Therefore, politicians may use social media not only to circumvent gatekeepers and directly reach their followers but also to gain attention in the news media.

Second, journalists seldom voice populist ideas themselves, but they readily provide a stage for populist messages by political actors in online news articles as well as by citizens in reader comments. Thus, journalists mainly act as gatekeepers for the dissemination of populist communication online and less as initiators or interpreters of populist messages. However, opinion-oriented journalism acts as a driver of populism by the media.

Third, populist online communication triggers more audience reactions and the expression of populist messages by citizens. Online populist communication (a) resonates with citizens by triggering more popularity cues on social media and more reader comments on online news platforms, and (b) multiplies by eliciting populist messages by citizens in reader comments. Thus, within an online context, citizens become a more central actor for the expression and dissemination of populist ideas.

Fourth, citizens' populist attitudes moderate the effects of populist online communication on audience reactions. Thus, only a limited, specific group of people spreads populist ideas online. Yet, this group seems to be especially active on social media and in comment sections and therefore contributes to the impression of an overrepresentation of populist messages.

\section{Concluding discussion and contribution}

Research on populism has long focused on the supply side, specifically on political actors. Only more recently has the role of the media in the dissemination of populist communication been taken into account. Furthermore, for a long time, citizens have been neglected as actors and have only been considered - at most - in their role as passive recipients of populist messages. However, the dissertation shows that the roles of politicians, the media, and citizens have become more interconnected and reciprocal in an online communication environment. Moreover, the boundary between the supply and the demand side has become increasingly blurred (see also Hameleers, 2018). This blurring must be considered when investigating the drivers and effects of populist online communication.

Based on these considerations, in the synopsis of my thesis (Blassnig, 2020) I propose a heuristic model of populist online communication that integrates the lessons learned in the dissertation and findings from the broader literature. As Figure 1 depicts, at the heart of this heuristic model lie the three components that together constitute populist online communication in its manifested form: (1) politicians' self-presentation, (2) journalistic media representation, and (3) citizens' (re) actions. As the double-headed arrows indicate, the three key aspects are expected to mutually influence each other. Additionally, the model includes influencing factors on three levels: (a) structural, situational, and cultural context factors on the macro level; (b) characteristics of political organizations, media organizations, and communication channels on the meso lev$\mathrm{el}$; and (c) characteristics of citizens on the micro level. In this brief summary, I want to focus on certain aspects that highlight the contribution of the dissertation.

Regarding politicians' self-presentation, the findings imply that populism in politicians' self-presentation may be influenced reciprocally by the media representation and citizens' reactions and by politicians' anticipation of their logics and response. This suggests a rather strategic use of populist communication by political actors to get attention from voters or in the media. If politicians presume that pop- 
Figure 1: Heuristic model for research on populist online presentation

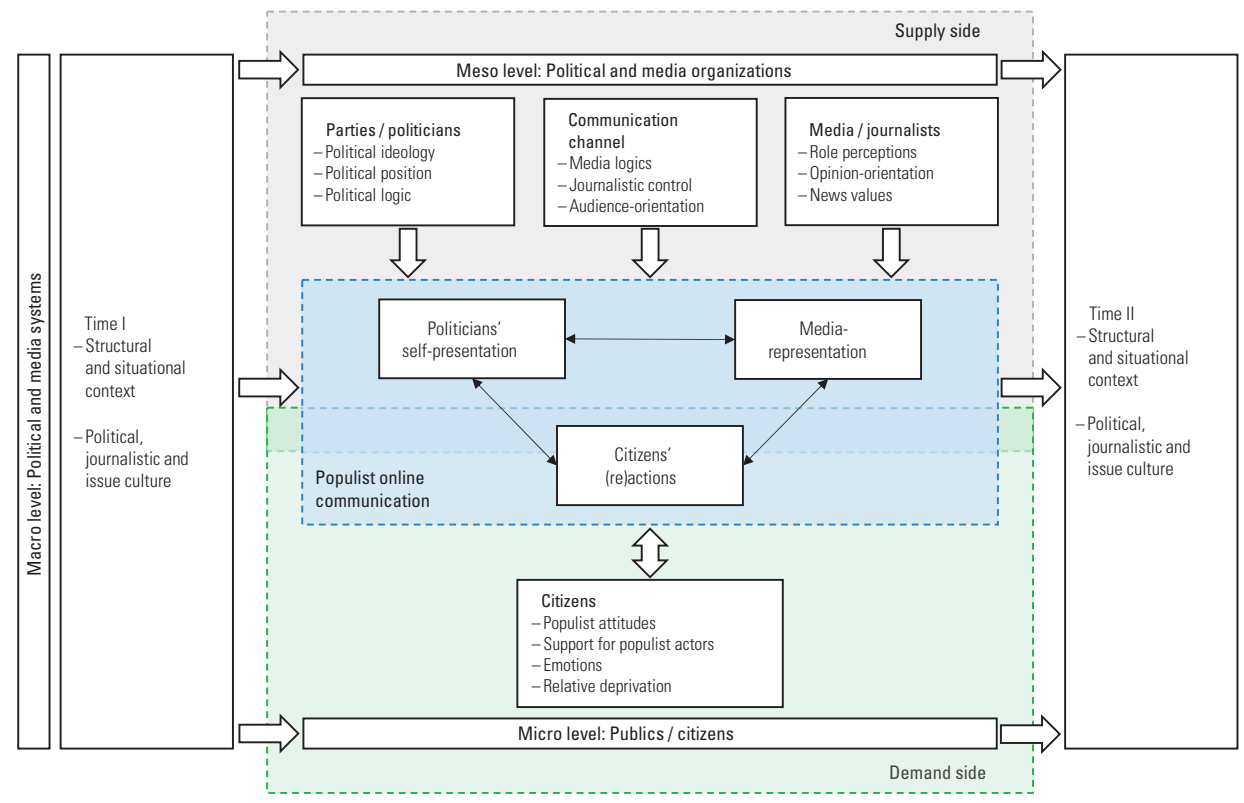

Note. Own presentation based on Blassnig (2020).

ulist messages might receive more attention in the news media and more popularity cues on social media, this could provide an incentive to use populist communication strategically.

The media representation of populist communication is influenced by characteristics of media organizations, journalists, and the communication channel. The predominance of populism through the media found in the dissertation can be explained by populism's fit with media logic and news values. Additionally, populism in politicians' self-presentation is expected to drive populism through the media, as journalists closely monitor politicians' social media statements and increasingly incorporate them as quotes in articles. For populism by the media, opinion orientation or interpretative journalism were identified as drivers. Thus, populism in online news could be driven or inhibited by specific journalistic role perceptions.

Citizens' (re)actions, finally, comprise reactions by citizens to populist messages by politicians or journalists as well as populist messages by citizens themselves. On the one hand, the dissertation argues that citizens' reactions are driven by populism in politicians' self-presentation and in the media representation. Thus, when considering citizens' role as recipients, audience reactions can be interpreted as effects of populist communication. On the other hand, I argue that citizens can exert a more active role within an online environment as initiators, gatewatchers (Bruns, 2018), or interpreters of populist messages.

This has two implications for the relationship between the demand and the supply side of populist communication. First, the distinction between the two is becoming increasingly blurry and overlapping, as citizens can be both recipients and senders of populist messages (Hameleers, 2018). Second, these findings can be connected to a general "shift from a supply to a demand market in communication" (Brants \& van Praag, 2015, p. 395). Journalists and politicians increasingly anticipate what they assume to be the people's needs, requests, frustrations, and resentments and adapt their behavior or communication accordingly (Brants \& van Praag, 2015, 
p. 404). This implies that populism in politicians' self-presentation and in the media is driven reciprocally by the anticipation of citizens' demands and reactions.

Overall, the model suggests that populist online communication is the outcome of the reciprocal interactions among politicians, journalists, and citizens, in which different logics interact, merge, and collide, and that is driven or inhibited by various factors on the macro, meso, and micro level. In this sense, many of the findings can be applied to political online communication in general. However, the dissertation looked only at a small selection of factors on these different levels of influence. Therefore, I see the proposed model not as exhaustive but more as a guiding concept for future research.

The dissertation also provides relevant societal and practical implications for politicians, the media, and citizens in liberal democracies. Regarding politicians, the findings imply that it could make sense to strategically adopt populist communication or focus on populism-affine issues to gain more attention by both the media and citizens. However, mainstream politicians may also face a backlash from voters - specifically from those with low populist attitudes - if they suddenly imitate populist actors. In terms of the media, the dissertation has demonstrated that most populism in online news stems either from cited statements by politicians that are often disseminated uncritically, opinion-oriented formats, or reader comments. Therefore, journalists and media organizations must critically reflect their role as gatekeepers and interpreters of populist messages by politicians and citizens. For instance, journalists should not mistake popularity for relevance (Bruns, 2018, pp. 230-231). Another central finding is that populism in social media posts or news articles leads to more frequent and more populist reactions by citizens. Considering populism's problematic stance on central ideas of liberal democracy, this multiplication and propagation of populist ideas to a larger audience through citizens is highly problematic. In contrast, from the viewpoint of participatory de- mocracy, it can also be interpreted as positive if populist communication would contribute to the increased participation of citizens and possibly opinion diversity in the online public sphere. Yet, liking, sharing, or commenting provides citizens with an easy means of responding directly and immediately to politicians or journalists online, but may not actually translate into real-world political actions or influence. This "lopsided efficacy" (Blumler, 2013) may further deepen the perceived chasm between "the people" and "the elite" that is propagated by populist ideology. Finally, the dissertation shows that specific groups are more likely to react to populist messages than others are. This finding corroborates earlier research and reinforces the argument that populist communication contributes to an increasing polarization of society into populist and anti-populist camps (see also Müller et al., 2017; Wirz, 2019). These developments present politicians, journalists, and citizens with major challenges and require further investigation. I hope that my dissertation will provide the foundation and serve as inspiration for such future research.

\section{Acknowledgements}

I want to thank the SACM for the honor of receiving this award. I would also like to express my sincere gratitude once again to my supervisor Frank Esser, my co-supervisor Keren Tenenboim-Weinblatt, and my co-authors on all related publications.

\section{Conflict of interests}

The author declares no conflict of interests.

\section{References}

Aalberg, T., \& de Vreese, C. H. (2017). Introduction: Comprehending populist political communication. In T. Aalberg, F. Esser, C. Reinemann, J. Strömbäck, \& C. H. de Vreese (Eds.), Populist political communi- 
cation in Europe (pp. 3-11). New York, NY: Routledge.

Akkerman, A., Mudde, C., \& Zaslove, A. (2014). How populist are the people? Measuring populist attitudes in voters. Comparative Political Studies, 47(9), 1324-1353. https:// doi.org/10.1177/0010414013512600

Albertazzi, D., \& McDonnell, D. (2008). Introduction: A new spectre for Western Europe. In D. Albertazzi \& D. McDonnell (Eds.), Twenty-first century populism: The spectre of Western European democracy (pp. 1-11). Basingstoke, UK: Palgrave Macmillan.

Bimber, B. (1998). The Internet and political transformation: Populism, community, and accelerated pluralism. Polity, 31(1), 133-160. https://doi.org/10.2307/3235370

Blassnig, S. (2020). Populist online communication - interactions among politicians, journalists, and citizens (Dissertation). Faculty of Arts and Social Sciences, University of Zurich, Zurich, Switzerland.

Blassnig, S., Engesser, S., Ernst, N., \& Esser, F. (2019). Hitting a nerve: Populist news articles lead to more frequent and more populist reader comments. Political Communication, 36(4), 629-651. https:// doi.org/10.1080/10584609.2019.1637980

Blassnig, S., Ernst, N., Büchel, F., \& Engesser, S. (2018). Populist communication in talk shows and social media. A comparative content analysis in four countries. Studies in Communication and Media, 7(3), 338-363. https://doi.org/10.5771/21924007-2018-3-338

Blassnig, S., Ernst, N., Büchel, F., Engesser, S., \& Esser, F. (2019). Populism in online election coverage. Journalism Studies, 20(8), 1110-1129. https://doi.org/10.1080/14616 70X.2018.1487802

Blassnig, S., Ernst, N., Engesser, S., \& Esser, F. (2020). Populism and social media popularity: How populist communication benefits political leaders on Facebook and Twitter. In R. Davis \& D. Taras (Eds.), Power shift? Political leadership and social media (pp. 97-111). New York, NY: Routledge.

Blassnig, S., \&Wirz, D. S. (2019). Populist and popular: An experiment on the drivers of user reactions to populist posts on Facebook. Social Me- dia + Society, 5(4), 1-12. https://doi. org/10.1177/2056305119890062

Blumler, J. G. (2013, September 12). The fourth age of political communication: Keynote address delivered at a workshop on political communication online. Free University of Berlin.

Blumler, J. G., \& Kavanagh, D. (1999). The third age of political communication: Influences and features. Political Communication, 16(3), 209-230. https://doi. org / 10.1080/105846099198596

Brants, K., \& van Praag, P. (2015). Beyond media logic. Journalism Studies, 18(4), 395-408. https://doi.org/10.1080/146167 0X.2015.1065200

Bruns, A. (2018). Gatewatching and news curation: Journalism, social media, and the public sphere. New York, NY: Peter Lang.

Chadwick, A. (2017). The hybrid media system: Politics and power (2nd ed.). Oxford, UK: Oxford University Press.

Cranmer, M. (2011). Populist communication and publicity: An empirical study of contextual differences in Switzerland. Swiss Political Science Review, 17(3), 286-307. https://doi.org/10.1111/j.16626370.2011.02019.x

Dahlberg, L. (2001). The Internet and democratic discourse: Exploring the prospects of online deliberative forums extending the public sphere. Information, Communication \& Society, 4(4), 615-633. https://doi. org/10.1080/13691180110097030

de Vreese, C. H., Esser, F., Aalberg, T., Reinemann, C., \& Stanyer, J. (2018). Populism as an expression of political communication content and style: A new perspective. The International Journal of Press/ Politics, 23(4), 423-438. https://doi. org/10.1177/1940161218790035

Engesser, S., Fawzi, N., \& Larsson, A. O. (2017). Populist online communication: Introduction to the special issue. Information, Communication \& Society, 20(9), 1279-1292. https://doi.org/10.1080/13691 18X.2017.1328525

Ernst, N., Engesser, S., Büchel, F., Blassnig, S., \& Esser, F. (2017). Extreme parties and populism: An analysis of Facebook and Twitter across six countries. Information, Communication \& Society, 20(9), 
1347-1364. https://doi.org/10.1080/13691 18X.2017.1329333

Ernst, N., Esser, F., Blassnig, S., \& Engesser, S. (2019). Favorable opportunity structures for populist communication: Comparing different types of politicians and issues in social media, television and the press. The International Journal of Press/Politics, 24(2), 165-188. https://doi. org/10.1177/1940161218819430

Esser, F., \& Hanitzsch, T. (2012). On the why and how of comparative inquiry in communication studies. In F. Esser \& T. Hanitzsch (Eds.), Handbook of comparative communication research (pp. 3-22). New York, NY: Routledge.

Esser, F., Stępińska, A., \& Hopmann, D. N. (2017). Populism and the media: Crossnational findings and perspectives. In T. Aalberg, F. Esser, C. Reinemann, J. Strömbäck, \& C. H. de Vreese (Eds.), Populist political communication in Europe (pp. 365-380). New York, NY: Routledge.

Esser, F., \& Vliegenthart, R. (2017). Comparative research methods. In J. Matthes (Ed.), The international encyclopedia of communication research methods (pp. 1-22). Hoboken, NJ: John Wiley \& Sons, Inc. https://doi.org/10.1002/9781118901731. iecrm0035

Freelon, D. (2015). Discourse architecture, ideology, and democratic norms in online political discussion. New Media \& Society, 17(5), 772-791. https://doi. org/10.1177/1461444813513259

Hameleers, M. (2018). A typology of populism: Toward a revised theoretical framework on the sender side and receiver side of communication. International Journal of Communication, 12, 2171-2190. Retrieved from https://ijoc.org/index.php/ijoc/article/view/7456/2353

Hameleers, M., Bos, L., \& de Vreese, C. H. (2017). "They did it": The effects of emotionalized blame attribution in populist communication. Communication Research, 44(6), 870-900. https://doi. org/10.1177/0093650216644026

Hawkins, K. A., \& Kaltwasser, C. R. (2018). Introduction: The ideational approach. In K. A. Hawkins, R. E. Carlin, L. Littvay, \& C. Rovira Kaltwasser (Eds.), The ideational approach to populism: Concept, theory, and analysis (pp. 1-24). London, UK: Routledge.

Humprecht, E. (2016). Shaping online news performance: Political news in six Western democracies. Challenges to democracy in the $21^{\text {st }}$ century. Basingstoke, UK: Palgrave Macmillan.

Jagers, J., \& Walgrave, S. (2007). Populism as political communication style: An empirical study of political parties' discourse in Belgium. European Journal of Political Research, 46(3), 319-345. https://doi. org/10.1111/j.1475-6765.2006.00690.x

Klinger, U., \& Svensson, J. (2015). The emergence of network media logic in political communication: A theoretical approach. New Media \& Society, 17(8), 1241-1257. https://doi. org/10.1177/1461444814522952

Krämer, B. (2014). Media populism: A conceptual clarification and some theses on its effects. Communication Theory, 24(1), 4260. https://doi.org/10.1111/comt.12029

Landerer, N. (2013). Rethinking the logics: A conceptual framework for the mediatization of politics. Communication Theory, 23(3), 239-258. https://doi.org/10.1111/ comt.12013

Mazzoleni, G. (2008). Populism and the media. In D. Albertazzi \& D. McDonnell (Eds.), Twenty-first century populism: The spectre of Western European democracy (pp. 4964). Basingstoke, UK: Palgrave Macmillan.

Mény, Y., \& Surel, Y. (2002). The constitutitive ambiguity of populism. In Y. Mény \&Y. Surel (Eds.), Democracies and the populist challenge (pp. 1-21). Basingstoke, UK: Palgrave.

Mudde, C. (2004). The populist zeitgeist. Government and Opposition, 39(4), 541-563. https://doi.org/10.1111/ j.1477-7053.2004.00135.x

Müller, P., Schemer, C., Wettstein, M., Schulz, A., Wirz, D. S., Engesser, S., \& Wirth, W. (2017). The polarizing impact of news coverage on populist attitudes in the public: Evidence from a panel study in four European democracies. Journal of Communication, 67(6), 968-992. https://doi. org/10.1111/jcom. 12337

Parmelee, J. H., \& Bichard, S. L. (2012). Politics and the Twitter revolution: How tweets 
influence the relationship between political leaders and the public. Lanham, MD: Lexington Books.

Porten-Cheé, P., Haßler, J., Jost, P., Eilders, C., \& Maurer, M. (2018). Popularity cues in online media: Theoretical and methodological perspectives. Studies in Communication and Media, 7(2), 208-230. https://doi. org/10.5771/2192-4007-2018-2-80

Roskos-Ewoldsen, D. R., Roskos-Ewoldsen, B., \& Carpentier, F. R. D. (2002). Media priming: A synthesis. In J. Bryant \& D. Zillmann (Eds.), Media effects: Advances in theory and research (2nd ed., pp. 97-120). Mahwah, NJ: Lawrence Elbaum.

Salvini, M. (2018, February 6). Gli altri hanno televisioni, giornali e radio, noi abbiamo TE [The others have newspapers, radio, television, banks, and corporate moneywe have you]! [Facebook status update]. Retrieved from https://www.facebook. com/story.php?story_fbid $=1015551735525$ 8155\&id $=252306033154$

Stanyer, J., Salgado, S., \& Strömbäck, J. (2017). Populist actors as communicators or political actors as populist communicators: Cross-national findings and perspectives. In T. Aalberg, F. Esser, C. Reinemann, J. Strömbäck, \& C. H. de Vreese (Eds.), Populist political communication in Europe (pp. 353-364). New York, NY: Routledge.

Toepfl, F., \& Piwoni, E. (2015). Public spheres in interaction: Comment sections of news websites as counterpublic spaces. Journal of Communication, 65(3), 465-488. https://doi.org/10.1111/jcom.12156 van Zomeren, M., Postmes, T., \& Spears, R. (2008). Toward an integrative social identity model of collective action: A quantitative research synthesis of three socio-psychological perspectives. Psychological Bulletin, 134(4), 504-535. https:// doi.org/10.1037/0033-2909.134.4.504

Wettstein, M., Esser, F., Schulz, A., Wirz, D. S., \&Wirth, W. (2018). News media as gatekeepers, critics, and initiators of populist communication: How journalists in ten countries deal with the populist challenge. The International Journal of Press/Politics, 23(4), 476-495. https://doi. org/10.1177/1940161218785979

Wirth, W., Esser, F., Engesser, S., Wirz, D. S., Schulz, A., Ernst, N., ... Schemer, C. (2016). The appeal of populist ideas, strategies and styles: A theoretical model and research design for analyzing populist political communication. Zurich: NCCR democracy working paper. https://doi.org/10.5167/ uzh-127461

Wirz, D. S. (2018). Persuasion through emotion? An experimental test of the emotion-eliciting nature of populist communication. International Journal of Communication, 12, 1114-1138. Retrieved from https://ijoc.org/index.php/ijoc/article/ view/7846/2287

Wirz, D. S. (2019). The populist persuasion: Persuasive Wirkungen inhaltlicher und formaler Merkmale populistischer Koтmunikation auf politische Einstellungen [The populist persuasion: Persuasive effects of content-related and formal features of populist communication on political attitudes] (Dissertation). University of Zurich, Zurich, Switzerland. 